\title{
Effect on digestion and performance of dietary protein content and of increased substitution of lucerne hay with soya-bean protein concentrate in starter diets for young rabbits
}

\author{
S. Chamorro ${ }^{1}$, M. S. Gómez-Conde ${ }^{1}$, A. M. Pérez de Rozas ${ }^{2}$, I. Badiola ${ }^{2}$, R. Carabaño ${ }^{1 \dagger}$ \\ and J. C. De Blas ${ }^{1}$ \\ ${ }^{1}$ Departamento de Producción Animal, ETS Ingenieros Agrónomos, Universidad Politécnica 28040, Madrid, Spain; ${ }^{2}$ CreSA (UAB-IRTA), Bellaterra, 08193, \\ Barcelona, Spain
}

(Received 22 September 2006; Accepted 1 February 2007)

\begin{abstract}
The aim of this work was to study the effect of protein source / availability on the intestinal microbiota, digestive traits and nutritional performance of early-weaned rabbits. The effects of supplemental antibiotics in the drinking water were also evaluated. Four isoenergetic and isofibrous diets were formulated: a control diet with a high protein (207 g/kg dry matter (DM)) and lucerne hay content (HPHL), a diet with low crude protein (CP) (179 g/kg DM) and high lucerne hay content (LPHL) and low protein diets in which the lucerne hay in diet LPHL was replaced partially (LPML) or totally (LPLL) with soya-bean protein concentrate. Rabbits, weaned at 25 days (52 per diet), were fed the experimental diets for a 2-week period and thereafter received a commercial diet until 56 days of age. The incidence of mortality was investigated using 70 animals per diet without supplemental medication. The profile of the ileal microbiota was studied at 35 days of age in rabbits treated (18 per diet) or not (12 per diet) with antibiotic. As expected, supplementation with antibiotics effectively reduced fattening mortality rate and microbial biodiversity. However, lowering of also the dietary $C P$ content led to a reduction in the mortality rate $(\mathrm{P}<0.05)$, both in animals treated with (by $80 \%)$ or without (by 39\%) antibiotics. In addition, there was a reduction $(\mathrm{P}<0.05)$ in the frequency of Clostridium perfringens in nonmedicated animals. Neither jejunal morphology nor growth performance, over the whole fattening period, was affected by dietary $C P$ content of the experimental diets. However, with HPHL, feed efficiency was higher (by 4.8\%; P < 0.01) than with LPHL diets. Substitution of lucerne hay with soya-bean meal in low protein diets did not affect apparent faecal or ileal digestibility of DM and $C P$. However, the ileal digestibility of cystine, alanine, aspartic acid, and proline was lowered $(P<0.05)$ with increasing substitution by soya bean. Nevertheless, ileal CP flow, incidence of mortality and presence of $C$. perfringens were unaffected. Our results suggest that a reduction in dietary $C P$, resulting in reduced lumenal flows of nitrogen through the ileum, may be beneficial for young rabbits and limit the numbers of potentially harmful bacteria in the lower gut. Modulation of dietary CP should be contemplated as a strategy to increase the intestinal health in rabbits.
\end{abstract}

Keywords: feed efficiency, microbial flora, protein intake, protein sources, rabbits

\section{Introduction}

Around the weaning, pathologies occur in a context of incomplete development of the digestive physiology. Up to now, the use of antibiotics seems to have been the most effective way to control the high mortality associated with enteric disorders, by limiting the pathogenic microbiota. The supply of balanced diets has also been related with the prevention of disorders by means of two mechanisms: (i) promoting a lower retention time of the digesta in the digestive tract, or (ii) causing a lower flow of easily

\footnotetext{
${ }^{\dagger}$ E-mail: rosa.carabano@upm.es
}

available substrates into the fermentative area. The alteration of the gut microbiota has been postulated as the possible primary cause of these pathologies. In the case of the rabbit, the dietary factors more related with the incidence of enteric disease are the levels of starch and fibre, usually inversely correlated, and the type of fibre (Blas and Gidenne, 1998; De Blas et al., 1999; Gidenne, 2000) but little attention has been paid up to now on the role of the protein.

Some previous studies have shown that diets with a high level of protein $(>180 \mathrm{~g} / \mathrm{kg})$ promoted in rabbits an increase of Clostridium population (Haffar et al., 1988) and a higher incidence of digestive problems around weaning (De Blas 
Chamorro, Gómez-Conde, Pérez de Rozas, Badiola, Carabaño and De Blas

et al., 1981; Maertens and De Groote, 1988), that also occurred when low ileal digestible protein sources were included in the diet (Gutiérrez et al., 2003). These results might be explained by a higher availability of substrates for microbial growth, as proteolytic activity has been proven to be relevant in the caecum of rabbits (Emaldi et al., 1979). Works in other non-ruminant species such as broiler chickens (Drew et al., 2004) and dogs (Zentek et al., 2004) also showed a positive relationship between level of protein and intestinal proliferation of Clostridium perfringens population. However, the hypothetical effect of diet (promoting changes in availability of protein at ileum and caecum) on the development of pathogenic bacteria and the outbreak of digestive disorders has not been tested in rabbits.

Otherwise, a reduction in the protein dietary supply might affect growth rate, maturation and functionality of intestinal mucosa, which acts as a first line of defence against dietary toxins and pathogens. Some studies in early-weaned piglets have shown that low protein diets led to an atrophy of intestinal mucosa and to a reduction in its absorptive and immunological capacity (Nunez et al., 1996; Gu and Li, 2004). There is a lack of information on the role of level of dietary protein in mucosal functionality in rabbits, although previous work indicate that the villus atrophy observed at weaning (Gutiérrez et al., 2002a) might be alleviated through the dietary supply of high quality animal plasma (Gutiérrez et al., 2000).

The aim of this work was to study the effect of a reduction of the ileal protein flow, by decreasing the dietary level of protein or by increasing protein ileal digestibility, on digestive traits, mucosal morphology and growth performance, and its interactions with the antibiotic supplementation on composition of intestinal microbiota and incidence of enteric disease.

\section{Material and methods}

\section{Diets}

Four isoenergetic and isofibrous diets were formulated to induce differences in the ileal flow of crude protein (CP) through changes in the dietary level and the apparent ileal digestibility of protein. A basal diet with a high protein and lucerne hay content (HPHL) was formulated according to De Blas and Mateos (1998) and recent works on optimal starter feed composition (Gutiérrez et al., 2002a and b and 2003). Another diet (LPHL; low CP, high lucerne hay) was designed by substituting dietary starch for $\mathrm{CP}$, maintaining the apparent ileal CP digestibility of the diets according to an estimation made from previous works (García et al., 2005). Two additional low protein diets were formulated further to reduce the ileal flow of protein by replacing lucerne hay in diet LPHL with a more digestible protein source (soya-bean protein concentrate) plus a mixture of fibrous ingredients (sunflower hull, sugar beet and apple pulp), totally (LPLL) or partially (LPML). All the diets were pelleted and included $5 \mathrm{~g} / \mathrm{kg}$ of lucerne hay marked with an indigestible marker (ytterbium) according to the procedure described by García et al. (1999). The ingredients and chemical composition of the diets are shown in Tables 1 and 2.

Faecal digestibility trial

Forty rabbits weighing 464 (s.e. 18) g at 25 days of age, were blocked by litter and assigned at random to the experimental diets (10 per diet) to determine the apparent faecal digestibility of dry matter (DM), CP and energy. Rabbits were individually caged and had ad libitum access to the food during the experimental period. Following a 1-week adaptation period, the feed intake and total faecal output (caecotrophy was not prevented) were recorded from 32 to 35 days of age. The faeces daily collected were stored at $-20^{\circ} \mathrm{C}$, dried at $80^{\circ} \mathrm{C}$ for $48 \mathrm{~h}$ and ground to pass a 1-mm sieve for analysis.

\section{Ileal digestibility trial}

Sixty four rabbits weighing 454 (s.e. 19) g at 25 days of age were blocked by litter and assigned at random to the experimental diets (16 per diet) to determine the apparent ileal digestibility of DM, CP and amino acids (AA). Following a 10-day adaptation period, animals were slaughtered by cervical dislocation weighing 788 (s.e. 33) g. Slaughter time was between 1900 and $2100 \mathrm{~h}$ to avoid the influence of caecotrophy on the chemical composition of the digesta (Merino and Carabaño, 2003). The last $20 \mathrm{~cm}$ of the ileum were taken and the ileal contents were removed, frozen and freeze-dried. The samples were then ground and, because of the small quantity available, they were pooled in groups of two rabbits of the same treatment to analyse

Table 1 Ingredients in the experimental diets $(\mathrm{g} / \mathrm{kg})$

\begin{tabular}{lcrrr}
\hline \hline & \multicolumn{4}{c}{ Diets $^{\dagger}$} \\
\cline { 2 - 5 } & HPHL & LPHL & LPML & LPLL \\
\hline Wheat & 195 & 300 & 300 & 300 \\
Wheat bran & 300 & 140 & 140 & 140 \\
Sunflower meal & 130 & 50 & 50 & 50 \\
Lucerne hay & 335 & 369 & 182 & 0 \\
Lucerne hay-Yb & 5 & 5 & 5 & 5 \\
Sunflower hulls & 0 & 0 & 14 & 28 \\
Soya-bean protein concentrate & 0 & 0 & 37 & 74 \\
Apple pulp & 0 & 0 & 67 & 135 \\
Beet pulp & 0 & 0 & 55 & 110 \\
Wheat straw & 0 & 89 & 102 & 111 \\
Lard & 20 & 30 & 26 & 22 \\
L-Lysine HCl 78 & 4.1 & 5.7 & 5.2 & 4.7 \\
DL-Methionine 99 & 0.4 & 1.7 & 1.8 & 1.8 \\
L-Threonine & 0.8 & 1.6 & 1.8 & 1.8 \\
Calcium carbonate & 0 & 0 & 5 & 10 \\
Sodium chloride & 5 & 5 & 5 & 5 \\
Vitamin/mineral pre-mix ${ }^{\ddagger}$ & 5 & 5 & 5 & 5 \\
\hline \hline
\end{tabular}

${ }^{\dagger} \mathrm{HPHL}=$ high protein high lucerne-hay. LPHL = low protein high lucernehay. $\mathrm{LPML}=$ low protein medium lucerne-hay. $\mathrm{LPLL}=$ low protein low lucerne-hay.

${ }^{\ddagger}$ Provided by Trouw Nutrition España S.A. (Madrid, Spain): mineral and vitamin composition (mg/kg feed): $\mathrm{Mg}, 290 ; \mathrm{Na}, 329 ; \mathrm{S}, 275 ; \mathrm{Co}, 0.7 ; \mathrm{Cu}, 10 ; \mathrm{Fe}$, 76; Mn, 20; Zn, 59.2; I, 1.25; choline, 250; riboflavin, 2; niacin, 20; pyridoxine, 1; phytylmetaquinone, 1; alpha-tocopherol, 13; thiamine, 1; retinol, 2.5, and cholecalciferol, 0.019 . 
Table 2 Chemical composition of experimental diets ( $\mathrm{g} / \mathrm{kg}$ dry matter)

\begin{tabular}{lcccc}
\hline & \multicolumn{4}{c}{ Diets $^{\dagger}$} \\
\cline { 2 - 5 } & HPHL & LPHL & LPML & LPLL \\
\hline Dry matter & 911 & 908 & 909 & 912 \\
Ash & 82.8 & 80.6 & 75.7 & 63.0 \\
Crude protein & 207 & 179 & 174 & 176 \\
Starch & 200 & 227 & 224 & 220 \\
Neutral-detergent fibre (NDF) & 329 & 335 & 355 & 363 \\
Acid-detergent fibre (ADF) & 165 & 173 & 183 & 185 \\
Acid-detergent lignin (ADL) & 46.3 & 46.9 & 51.4 & 55.7 \\
Gross energy (MJ/kg DM) & 19.1 & 18.8 & 18.9 & 19.2 \\
Digestible energy (MJ/kg DM) & 14.0 & 13.7 & 13.7 & 14.1 \\
Arginine & 11.8 & 8.75 & 9.29 & 9.49 \\
Cystine & 3.85 & 3.91 & 3.60 & 3.22 \\
Histidine & 4.51 & 3.45 & 3.66 & 3.74 \\
Isoleucine & 7.13 & 5.79 & 5.98 & 5.97 \\
Leucine & 12.9 & 10.7 & 10.5 & 10.7 \\
Lysine & 11.0 & 10.6 & 10.5 & 10.7 \\
Methionine & 4.93 & 4.95 & 4.67 & 4.85 \\
Phenylalanine & 8.11 & 6.87 & 7.02 & 7.29 \\
Threonine & 8.07 & 7.59 & 7.39 & 7.40 \\
Valine & 8.90 & 7.11 & 7.25 & 7.15 \\
Alanine & 8.93 & 7.53 & 7.17 & 6.67 \\
Aspartic acid & 17.8 & 15.2 & 14.4 & 13.1 \\
Glutamic acid & 37.3 & 29.5 & 31.2 & 32.4 \\
Glycine & 9.94 & 7.85 & 7.55 & 7.18 \\
Proline & 13.6 & 12.1 & 11.6 & 9.93 \\
Serine & 8.17 & 5.99 & 6.30 & 6.69 \\
Tyrosine & 5.21 & 4.66 & 4.88 & 4.71 \\
\hline \hline & & & & \\
\hline & & & &
\end{tabular}

${ }^{\dagger} \mathrm{HPHL}=$ high protein high lucerne-hay. LPHL = low protein high lucernehay. $\mathrm{LPML}=$ low protein medium lucerne-hay. $\mathrm{LPLL}=$ low protein low lucerne-hay.

$\mathrm{CP}$ and ytterbium. To determine the AA content of the ileal digesta, a fixed amount $(0.05 \mathrm{~g})$ of all the samples belonging to each treatment were pooled. Ytterbium content of experimental diets and ileal digesta were analysed to calculate apparent ileal digestibility of $\mathrm{CP}$ and $\mathrm{AA}\left(\mathrm{CP}_{\mathrm{id}}\right.$ and $A A_{\text {id }}$ according to the following equations):

$$
\begin{aligned}
\mathrm{CP}_{\text {id }}= & {[1-\text { dietary ytterbium concentration }} \\
& \times \text { ileal } \mathrm{CP} \text { concentration } / \\
& \text { ileal ytterbium concentration } \\
& \times \text { dietary } \mathrm{CP} \text { concentration })] \times 100 .
\end{aligned}
$$

$$
\begin{aligned}
A A_{i d}= & {[1-(\text { dietary ytterbium concentration }} \\
& \times \text { ileal amino acid concentration } / \\
& \text { ileal ytterbium concentration } \\
& \times \text { dietary amino acid concentration })] \times 100 .
\end{aligned}
$$

\section{Digestive traits trial}

Sixty weanling mixed-sex rabbits (15 animals per diet) 25 days old and weighing $501 \pm 16 \mathrm{~g}$, were fed the experimental diets up to 35 days of age. Final weight was
$922 \pm 43 \mathrm{~g}$. Rabbits were individually caged and had ad libitum access to the food during the experimental period. Animals were slaughtered by cervical dislocation between 1900 and $2100 \mathrm{~h}$ to avoid the caecotrophy period. After that, the gastro-intestinal tract was removed and weighed. Stomach and caecum were weighed separately with and without their contents. The pH of caecal and stomach contents was determined. In the stomach digesta, three measurements of $\mathrm{pH}$ were taken: at the pyloric and fundus areas, and in the mixture of both areas. A sample was taken from the middle part of the jejunum of each animal to determine mucosa histology. The samples were placed in a $10 \%$ buffered neutral formaldehyde solution $\mathrm{pH} 7.2$ to 7.4) and were gradually dehydrated with increasing concentrations of ethyl alcohol (50 to 100\%). These dehydrated specimens were first embedded in paraffin, prepared by sectioning at $6 \mu \mathrm{m}$, and stained with hematoxylin and eosin. The sections were analysed under a light microscope (Olympus BX40, Olympus Optical Co., 20097, Hamburg, Germany) to determine their morphometric index by computer-assisted image analysis (The ImageJ $v 1.26$. Wayne Rasband, National Institutes of Health, Bethesda, MD 20 892, USA). Villi heights (from the top of the villi to the villi crypt junction) at three cross sections were measured according to Hampson (1986) from the mean value of 30 vertically oriented villi per animal.

\section{Finishing performance trial}

Two hundred and eight New Zealand White $\times$ California weanling mixed-sex rabbits ( 52 per diet), 25 days old and $494 \pm 13 \mathrm{~g}$ live weight, were blocked by litter and assigned at random to the experimental diets. After weaning, rabbits were individually caged and were fed the experimental diets through a 2-week period. Drinking water was supplemented during this period with a mixture of $100 \mathrm{mg} / \mathrm{kg}$ of apramicine sulphate and $120 \mathrm{mg} / \mathrm{kg}$ of tylosin. After 39 days of age, all the animals received a commercial feed (CUNIUNIC $®$, NANTA, S.A.: $170 \mathrm{~g} \mathrm{CP,}$ $144 \mathrm{~g}$ starch, $373 \mathrm{~g}$ neutral-detergent fibre (NDF) and $49 \mathrm{~g}$ acid-detergent fibre (ADF) per $\mathrm{kg}$ ) until they reached 56 days of age. Animals had ad libitum access to the feed and water throughout the whole experimental period. Feed intake, weight gain and mortality rate at day 14 after weaning and at the end of the experimental period were recorded per cage. Mortality rate was also controlled in another group of 280 rabbits (70 per diet) weighing $498 \pm 13 \mathrm{~g}$ at 25 days of age. Animals were blocked by litter and assigned at random to the same dietary treatments, but they were not supplemented with antibiotics.

\section{Ileal microbiota characterisation trial}

One hundred and twenty 25-day-old rabbits (30 per diet) weighing $448 \pm 19 \mathrm{~g}$ live weight, were blocked by litter and assigned at random to the experimental diets during 10 days. Within each treatment, 18 animals received antibiotic supplementation in drinking water $(100 \mathrm{mg} / \mathrm{kg}$ of apramicine sulphate and $120 \mathrm{mg} / \mathrm{kg}$ of tylosin), whereas 
the other 12 rabbits were not supplemented. At 35 days of age the rabbits, weighing $860 \pm 30 \mathrm{~g}$, were slaughtered by cervical dislocation between 1900 and $2100 \mathrm{~h}$. One $\mathrm{g}$ of ileal digesta was collected in a sterile plastic tube that contained $3 \mathrm{ml}$ of $98 \%$ molecular biology grade ethanol and were stored at $4^{\circ} \mathrm{C}$ to be analysed by RFLP according to the following procedure:

A 400-mg sample of gut contents was processed for total DNA extraction using the QIAamp DNA Stool Mini Kit (Qiagen Inc., Chatsworth, CA) system, in accordance with the instructions of the manufacturer with two additional steps of lysozyme and proteinase $K$. The purified DNA was maintained at $-20^{\circ} \mathrm{C}$ until use. Two primers ( $5^{\prime}$-CTACGGGAGGCAGCAGT-3' and 5'-CCGTCWATTCMTTTGAGTTT-3') for regions I and II of the 16S rRNA gene (Lane, 1991), were used to amplify a DNA segment of 500 600 bp. PCR mixtures (PCR-Master Mix - Applied Biosystems - with $1.25 \mathrm{IU}$ of Taq polymerase, $50 \mathrm{ng}$ of DNA template, $0.2 \mu \mathrm{mol} / /$ the preceding primers, and distilled water in a total volume of $50 \mu \mathrm{l}$ ) were heated to $94^{\circ} \mathrm{C}$ for 5 min once, followed by 35 cycles of denaturation at $94^{\circ} \mathrm{C}$ for $1 \mathrm{~min}$, primer annealing at $45^{\circ} \mathrm{C}$ for $1 \mathrm{~min}$, and DNA extension at $72^{\circ} \mathrm{C}$ for $1 \mathrm{~min} 15 \mathrm{~s}$. The last extension cycle was continued for $5 \mathrm{~min}$. Aliquots of the amplified DNA fragments were digested, in separated tubes, with Alu I, Rsa I, Hpa II, Sau 3A I or Cfo I restriction endonucleases (Sigma-Aldrich) in accordance with manufacturer specifications. The endonuclease fragments were solved in $2 \%$ wide range agarose by electrophoresis at $150 \mathrm{~V}$ for $60 \mathrm{~min}$. The bands of DNA were visualised in an UV Chemigenious Image System (SynGene) using the GeneSnap software (SynGene). Pictures with $4.63 \mathrm{~s}$ exposure were stored. With the information resulting from the relative size of the restriction fragment length polymorphism (RFLP) bands, the information stored in the 'SSU_Una.gb' file from the Ribosomal Database Project (Maidak et al., 1997), and a specific software developed in our Institute, we could identify the bacterial genus or species compatible with the obtained RFLP profile. From each animal a biodiversity degree, defined as the number of $16 \mathrm{~S}$ r-DNA sequences, deposited in the Ribosomal Database Project, compatible with the RFLP profile obtained from the total DNA extracted from the gut samples, was recorder. Also, the frequency of the compatibility profile of every bacteria studied defined as the presence or absence of RFLP bands compatible with the theoretical RFLP bands for a certain genus or bacterial species was studied for every animal (i.e. a combination of bands with $92 \mathrm{bp}+467 \mathrm{bp}$ in Alul, plus $120 \mathrm{bp}+404 \mathrm{bp}+35 \mathrm{bp}$ bands in Rsal, plus $189 \mathrm{bp}+58 \mathrm{bp}+312 \mathrm{bp}$ bands in Hpall, plus $82 \mathrm{bp}+477 \mathrm{bp}$ bands in Sau3A, plus a band of $559 \mathrm{bp}$ in Cfol is compatible with C. perfringens. The absence of any of the above mentioned bands in the RFLP profile infer that the level of $C$. perfringens in the sample is below the detection level, as in other PCR-electrophoresis methods around $10^{4}-10^{5}$ DNA copies per $g$ of sample).
Housing

Animals were housed in wire metabolism cages measuring $250 \times 600 \times 330 \mathrm{~mm}$. A cycle of $12 \mathrm{~h}$ of light and $12 \mathrm{~h}$ of dark was used throughout the experiment. The light was switched on at $0730 \mathrm{~h}$. Heating and forced ventilation systems allowed the building temperature to be maintained between 18 and $23^{\circ} \mathrm{C}$ throughout the experiment. Rabbits were handled according to the principles for the care of animals in experimentation published by the Spanish Royal Decree 1201/2005 (2005). Because the trials were carried in a farm affected by epizootic rabbit enteropathy (ERE), animals were supplemented with antibiotics (100 mg/kg of apramicine sulphate and $120 \mathrm{mg} / \mathrm{kg}$ of tylosin) in drinking water. Mortality and ileal microbiota characterisation trial were additionally developed without supplementation in drinking water.

\section{Analytical methods}

Chemical analysis of diets and faeces was performed using the procedures of Association of Official Analytical Chemists (2000) for DM (930.15), ash (923.03), Dumas N (968.06) and starch (according to the alpha-amyloglucosidase method, 996.11). NDF, ADF and acid-detergent lignin were determined according to the sequential method of Van Soest et al. (1991). Gross energy (GE) was measured by adiabatic calorimetry. AAs were determined following acid hydrolysis using a Beckman System 6300HPA amino acid analyser (Fullerton, CA, USA). Samples were hydrolysed by reflux in $25 \mathrm{ml}$ of $6 \mathrm{~mol} / / \mathrm{HCl}$ with $10 \mathrm{~g} / \mathrm{l}$ added phenol for $24 \mathrm{~h}$ at $120^{\circ} \mathrm{C}$. For the determination of sulphur amino acids (methionine and cystine), samples were oxidised with performic acid at $0^{\circ} \mathrm{C}$ for $16 \mathrm{~h}$ and then, neutralised with $0.5 \mathrm{~g}$ of sodium meta-bisulphite before analysis. Tryptophan, being destroyed during acid hydrolysis, was not determined. Ytterbium content of diets and ileal digesta were analysed by atomic absorption spectrometry (Smith Hieftje 22, Thermo Jarrel Ash, MA, USA) using predosed samples to prepare common matrix standards. Previously, samples were ashed $\left(600^{\circ} \mathrm{C}\right)$ and then digested by boiling with a solution of $1.5 \mathrm{~mol} / / \mathrm{HNO}_{3}$ and $\mathrm{KCl}(3.81 \mathrm{~g} / \mathrm{l})$.

\section{Statistical analysis \\ Data from ileal and faecal digestibility, digestive traits and growth trials were analysed as a completely randomised- block design using type of diet as main effect and litter as block effect, by using the GLM procedure of Statistical Analysis Systems Institute (1991). Treatment sums of squares were partitioned into the effect of dietary level of protein (contrast of diets HPHL v. LPHL) and the linear and quadratic effects of level of substitution of lucerne hay with soya-bean protein concentrate (diets LPHL, LPML and LPLL). Weaning weight was used as a linear covariate in the growth traits analyses. \\ To analyse mortality, biodiversity degree and frequency of the compatibility profile, type of diet, antibiotic supplementation and their interaction were used as main effects. Mean comparisons of mortality and frequency}


of the compatibility profile traits were made using a chi-square test. Regression procedures were used to relate fattening mortality with frequency of the compatible profile of several entero-pathogenic bacteria.

\section{Results}

Digestibility trial

The effect of treatments on the ileal apparent digestibility (IAD) and faecal apparent digestibility (FAD) of experimental diets is shown in Table 3. Neither dietary protein level nor the substitution of lucerne hay with soya-bean concentrate affected FAD of DM, CP and GE $(0.724,0.829$ and 0.730 on average, respectively). The effect of a decrease in dietary protein concentration (207 v. $179 \mathrm{~g} / \mathrm{kg} \mathrm{DM}$ ) on the $I A D$ differed among $A A s$, as a reduction was observed for phenylalanine $(P<0.001)$, glycine $(P<0.05)$ and serine $(P<0.05)$ by 16,22 , and $9 \%$ respectively, whereas that of cystine increased by $18 \%(P<0.01)$ and no differences $(P>0.10)$ were detected for the other AAs. The substitution of lucerne hay with soya-bean concentrate led to a linear reduction of the IAD of cystine $(P<0.01)$, alanine $(P<0.05)$, aspartic acid $(P<0.01)$ and proline $(P<0.05)$ by respectively $18,10,13$, and $6 \%$ between extreme diets, and had a quadratic effect on methionine IAD $(P<0.05)$.
Digestion traits

The effect of dietary treatments on several digestive traits and jejunal morphology is presented in Table 4. Treatments did not affect pylorus and mixed digesta pH (1.56 and 2.02 on average, respectively). Animals fed HPHL diet had a lower fundus $\mathrm{pH}$ than those fed LPHL diet (1.97 v. 2.86, $P<0.05)$. The substitution of lucerne hay with soya-bean concentrate did not affect stomach $\mathrm{pH}$, but led to a linear effect on the caecal $\mathrm{pH}$, which decreased from 5.51 to 5.37 between extreme diets $(P<0.05)$, whereas dietary $C P$ concentration did not influence caecal pH (5.49, on average). No effect of treatments in the weights of stomach, caecum and their contents was detected. Neither dietary CP level nor source of protein affected villus height, crypt depth or the ratio villus height/crypt depth, which were on average $618 \mu \mathrm{m}, 135 \mu \mathrm{m}$ and 4.9 respectively.

\section{Finishing performance}

The effect of the dietary treatments on the finishing performance is shown in Table 5. During the first 2 weeks after weaning, when the animals were fed the experimental diets, neither dietary $\mathrm{CP}$ content nor source of protein affected weight gain or feed intake, which were on average 48.6 and $77.9 \mathrm{~g} /$ day, respectively. However, feed efficiency was $5 \%$ higher $(P<0.01)$ in animals fed HPHL with respect to $L P H L$ diets. In the whole fattening period the

Table 3 The effect of dietary treatments on the ileal and faecal apparent digestibility of experimental diet

\begin{tabular}{|c|c|c|c|c|c|c|c|c|}
\hline & \multicolumn{4}{|c|}{ Diets $^{\dagger}$} & \multirow[b]{2}{*}{ s.e. ${ }^{\ddagger}$} & \multicolumn{3}{|c|}{ Significance of effects $\S$} \\
\hline & HPHL & LPHL & LPML & LPLL & & 1 & 2 & 3 \\
\hline \multicolumn{9}{|c|}{ Ileal apparent digestibility } \\
\hline Dry matter & 0.470 & 0.466 & 0.457 & 0.499 & 0.016 & & & \\
\hline Crude protein & 0.602 & 0.609 & 0.612 & 0.635 & 0.020 & & & \\
\hline Arginine & 0.796 & 0.799 & 0.775 & 0.796 & 0.011 & & & \\
\hline Cystine & 0.603 & 0.707 & 0.617 & 0.578 & 0.018 & $* *$ & ** & \\
\hline Histidine & 0.723 & 0.699 & 0.680 & 0.704 & 0.015 & & & \\
\hline Isoleucine & 0.718 & 0.717 & 0.685 & 0.699 & 0.015 & & & \\
\hline Leucine & 0.731 & 0.739 & 0.697 & 0.710 & 0.014 & & & \\
\hline Lysine & 0.766 & 0.776 & 0.743 & 0.776 & 0.012 & & & \\
\hline Methionine & 0.771 & 0.788 & 0.735 & 0.777 & 0.012 & & & * \\
\hline Phenylalanine & 0.786 & 0.660 & 0.671 & 0.628 & 0.017 & $* * *$ & & \\
\hline Threonine & 0.657 & 0.676 & 0.642 & 0.635 & 0.017 & & & \\
\hline Valine & 0.684 & 0.683 & 0.654 & 0.681 & 0.016 & & & \\
\hline Alanine & 0.687 & 0.685 & 0.642 & 0.619 & 0.017 & & * & \\
\hline Aspartic acid & 0.712 & 0.722 & 0.660 & 0.626 & 0.016 & & ** & \\
\hline Glutamic acid & 0.812 & 0.805 & 0.789 & 0.799 & 0.010 & & & \\
\hline Glycine & 0.553 & 0.429 & 0.359 & 0.443 & 0.029 & * & & \\
\hline Proline & 0.794 & 0.793 & 0.766 & 0.742 & 0.011 & & * & \\
\hline Serine & 0.678 & 0.614 & 0.603 & 0.642 & 0.019 & * & & \\
\hline Tyrosine & 0.761 & 0.740 & 0.725 & 0.737 & 0.013 & & & \\
\hline \multicolumn{9}{|c|}{ Faecal apparent digestibility } \\
\hline Dry matter & 0.725 & 0.722 & 0.720 & 0.729 & 0.006 & & & \\
\hline Crude protein & 0.814 & 0.829 & 0.829 & 0.842 & 0.007 & & & \\
\hline Energy & 0.735 & 0.729 & 0.723 & 0.734 & 0.006 & & & \\
\hline
\end{tabular}

\footnotetext{
${ }^{\dagger} \mathrm{HPHL}=$ high protein high lucerne-hay. LPHL = low protein high lucerne-hay. LPML = low protein medium lucerne-hay. LPL $=$ low protein low lucerne-hay.

${ }^{\ddagger}$ Ileal apparent digestibility: no. $=8$. Faecal apparent digestibility: no. $=10$.

$\S 1=$ effect of level of protein (diet HPHL v. diet LPHL), $2=$ linear effect of dietary substitution of lucerne hay with soya-bean protein concentrate. $3=$ quadratic
} effect. 
Chamorro, Gómez-Conde, Pérez de Rozas, Badiola, Carabaño and De Blas

Table 4 The effect of dietary treatments on digestive traits and jejunal morphology

\begin{tabular}{|c|c|c|c|c|c|c|c|}
\hline & \multicolumn{4}{|c|}{ Diets $^{\dagger}$} & \multirow[b]{2}{*}{ s.e. ${ }^{\ddagger}$} & \multicolumn{2}{|c|}{$\begin{array}{l}\text { Significance } \\
\text { of effects } \S\end{array}$} \\
\hline & HPHL & LPHL & LPML & LPLL & & 1 & 2 \\
\hline Pylorus pH & 1.52 & 1.58 & 1.62 & 1.52 & 0.07 & & \\
\hline Fundus $\mathrm{pH}$ & 1.97 & 2.86 & 2.79 & 2.42 & 0.22 & * & \\
\hline Mixed digesta $\mathrm{pH}$ & 1.73 & 2.20 & 2.14 & 2.00 & 0.14 & & \\
\hline Caecal pH & 5.47 & 5.51 & 5.44 & 5.37 & 0.04 & & * \\
\hline \multicolumn{8}{|l|}{ Stomach } \\
\hline Organ $(\mathrm{g} / \mathrm{kg} \mathrm{LW})$ & 14.9 & 14.7 & 14.2 & 15.9 & 0.62 & & \\
\hline Content (g/kg LW) & 44.1 & 43.7 & 43.3 & 44.7 & 2.13 & & \\
\hline \multicolumn{8}{|l|}{ Caecum } \\
\hline Organ $(\mathrm{g} / \mathrm{kg} \mathrm{LW})$ & 19.8 & 18.7 & 21.1 & 19.9 & 0.79 & & \\
\hline Content (g/kg LW) & 73.0 & 66.0 & 67.1 & 70.9 & 3.13 & & \\
\hline \multicolumn{8}{|l|}{ Jejunal morphology } \\
\hline Villus height $(\mu \mathrm{m})$ & 632 & 606 & 636 & 600 & 48 & & \\
\hline Crypt depth $(\mu \mathrm{m})$ & 134 & 134 & 137 & 135 & 4.3 & & \\
\hline Villus height/crypt depth & 5.04 & 4.80 & 4.90 & 4.72 & 0.45 & & \\
\hline
\end{tabular}

${ }^{\dagger} \mathrm{HPHL}=$ High protein high lucerne-hay. LPHL = Low protein high lucerne-hay. LPML = Low protein medium lucerne-hay. LPLL = Low protein low lucerne-hay.

${ }^{\ddagger}$ no. $=15$ except for jejunal morphology where no. $=7$.

$\S 1$ = effect of level of protein (diet HPHL $v$. diet LPHL), 2 = linear effect of dietary substitution of lucerne hay with soya-bean protein concentrate. The quadratic effects were not significant.

dietary protein content did not influence any of the finishing performance traits studied. The linear substitution of lucerne hay with soya-bean concentrate reduced linearly feed intake $(P<0.05)$ and weight gain $(P<0.10)$, by 6 and $4 \%$, respectively between extreme diets, which resulted in a tendency to increase feed efficiency (from 0.396 to 0.404 ).

\section{Ileal microbiota characterisation and mortality}

The effect of dietary treatments on the biodiversity, the frequency of the compatibility profile of ileal microbiota and the mortality in the fattening period of rabbits supplemented or not with antibiotics is shown in Table 6 . Neither dietary protein level nor the substitution of lucerne hay with soya-bean concentrate affected the biodiversity of ileal microbiota, whereas the antibiotic supplementation led to a reduction $(P<0.001)$ from 1431 to 473 number of $16 \mathrm{~S}$ $r$-DNA sequences deposited in the Ribosomal Database Project, compatible with the RFLP profile obtained from the total DNA extracted from the gut samples. A significant interaction $(P<0.05)$ between dietary CP content and antibiotic supplementation was detected in the frequency of the compatibility profile of $C$. perfringens that decreased with dietary level of protein by $70 \%$ in

Table 5 The effect of dietary treatments on finishing performance

\begin{tabular}{|c|c|c|c|c|c|c|c|}
\hline & \multicolumn{4}{|c|}{ Diets $^{\dagger}$} & \multirow[b]{2}{*}{ s.e. ${ }^{\ddagger}$} & \multicolumn{2}{|c|}{$\begin{array}{l}\text { Significance } \\
\text { of effect }^{\S}\end{array}$} \\
\hline & HPHL & LPHL & LPML & LPLL & & 1 & 2 \\
\hline \multicolumn{8}{|l|}{ First 2 weeks after weaning period" } \\
\hline Weight gain (g/day) & 50.0 & 47.4 & 48.4 & 48.4 & 1.16 & & \\
\hline Feed intake (g/day) & 77.2 & 76.8 & 78.9 & 78.7 & 1.84 & & \\
\hline Feed efficiency (g gain per $g$ intake) & 0.648 & 0.617 & 0.618 & 0.616 & 0.007 & ** & \\
\hline \multicolumn{8}{|l|}{ Whole finishing period ( $25-56$ days) } \\
\hline Weight gain (g/day) & 49.9 & 49.3 & 48.6 & 47.3 & 0.77 & & ๆ \\
\hline Feed intake (g/day) & 125 & 125 & 123 & 118 & 2.09 & & * \\
\hline Feed efficiency (g gain per $g$ intake) & 0.399 & 0.396 & 0.397 & 0.404 & 0.003 & & ๆ \\
\hline
\end{tabular}

${ }^{\dagger} \mathrm{HPHL}=$ high protein high lucerne-hay. LPHL = low protein high lucerne-hay. LPML = low protein medium lucerne-hay. LPLL = low protein low lucerne-hay. ${ }^{\ddagger}$ no. $=42$.

$\S 1=$ effect of level of protein (diet HPHL v. diet LPHL), 2 = linear effect of dietary substitution of lucerne hay with soya-bean protein concentrate. The quadratic effects were not significant.

"Weaned at 25 days.

" Approaching significance $(P<0.10)$. 
Table 6 The effect of treatments on the biodiversity, the frequency of the compatibility profile (\%) of ileal microbiota and the mortality in fattening period of rabbits supplemented or not with antibiotics

\begin{tabular}{|c|c|c|c|c|c|c|c|c|c|c|c|c|c|}
\hline & \multicolumn{8}{|c|}{ Diets $^{\dagger}$} & \multicolumn{5}{|c|}{ Significance of contrasts ${ }^{\ddagger}$} \\
\hline & \multicolumn{4}{|c|}{ Antibiotic supplementation } & \multicolumn{4}{|c|}{ No antibiotic supplementation } & \multirow[b]{2}{*}{1} & \multirow[b]{2}{*}{2} & \multirow[b]{2}{*}{3} & \multirow[b]{2}{*}{4} & \multirow[b]{2}{*}{5} \\
\hline & HPHL & LPHL & LPML & LPLL & HPHL & LPHL & LPML & LPLL & & & & & \\
\hline Biodiversity ${ }^{\S}$ & 714 & 395 & 535 & 250 & 1400 & 1102 & 2457 & 764 & & & $* * *$ & & \\
\hline \multicolumn{14}{|c|}{ Frequency of the compatibility profile $(\%)^{\S}$} \\
\hline Campylobacter spp. & 38.9 & 22.2 & 16.7 & 16.7 & 100 & 75.0 & 58.3 & 100 & & & $* * *$ & & \\
\hline Clostridium spp. & 83.3 & 88.9 & 61.1 & 33.3 & 100 & 100 & 100 & 100 & & ** & $* * *$ & & ** \\
\hline Clostridium perfringens & 11.1 & 11.1 & 0.00 & 0.00 & 83.3 & 25.0 & 25.0 & 33.3 & * & & $* * *$ & * & \\
\hline Clostridium difficile & 0.00 & 5.56 & 5.56 & 5.56 & 8.33 & 16.7 & 33.3 & 58.3 & & १ & $* * *$ & & ף \\
\hline Escherichia coli & 5.56 & 0 & 5.56 & 0 & 25.0 & 16.7 & 41.7 & 8.3 & & & $* * *$ & & \\
\hline Helicobacter spp. & 44.4 & 27.8 & 22.2 & 27.8 & 100 & 83.3 & 66.7 & 91.7 & & & $* * *$ & & \\
\hline \multicolumn{14}{|l|}{ Mortality $(\%)^{\|}$} \\
\hline 14 days after weaning period & 7.69 & 1.92 & 1.92 & 0 & 32.9 & 20.0 & 22.9 & 20.0 & * & & $* * *$ & & \\
\hline Whole fattening period & 9.61 & 1.92 & 1.92 & 3.84 & 32.9 & 20.0 & 24.3 & 22.9 & * & & $* * *$ & & \\
\hline
\end{tabular}

${ }^{\dagger} \mathrm{HPHL}=$ high protein high lucerne-hay. LPHL = low protein high lucerne-hay. LPML = low protein medium lucerne-hay. LPLL $=$ low protein low lucerne-hay. ${ }^{\ddagger} 1$ = effect of level of protein (diet HPHL v. diet LPHL). $2=$ linear effect of dietary substitutions of lucerne hay with soya-bean protein concentrate. $3=$ effect of antibiotic supplementation. $4=$ interaction level of protein $\times$ antibiotic. $5=$ interaction substitutions of lucerne hay with soya-bean concentrate $\times$ antibiotic.

${ }^{\S}$ Antibiotic supplementation: no. $=18$. No antibiotic supplementation: no. $=12$.

"Antibiotic supplementation: no. $=52$. No antibiotic supplementation: no. $=70$.

"Approaching significance $(P<0.10)$.

non-medicated animals, whereas it was not affected in animals supplemented with antibiotics. Another significant interaction was found between the type of protein and antibiotic supplementation on frequency of the compatibility profile of Clostridium spp. $(P<0.01)$, which decreased with the substitution of lucerne hay by soya-bean concentrate but only in medicated animals (by $62 \%$ between extreme diets) and on that of $C$. difficile $(P<0.10)$, which increased linearly from 16.7 to $58.3 \%$ (by $71 \%$ ) between extreme diets only in non-medicated animals. The supplementation of drinking water with antibiotics decreased the frequency of the compatibility profile of each species studied $(72 \%$ on average, $P<0.001$ ), ranging from $33 \%$ for Clostridium spp. to $89 \%$ for Escherichia coli.

A reduction of dietary $\mathrm{CP}$ level decreased $(P<0.05)$ the mortality rate during the first 2 weeks after weaning (when animals received experimental diets) and in the whole fattening period, both in animals supplemented or not with antibiotics. The substitution of lucerne hay with soya-bean concentrate did not affect this trait. Medication of drinking water reduced $(P<0.001)$ the mortality rate, both during the first 2 weeks after weaning and in the whole fattening period by around $83 \%$.

\section{Discussion}

A reduction of dietary protein content did not affect, as expected, the IAD of DM, CP and that of most of the AA. However, glycine, serine and phenylalanine IAD decreased, whereas that of cystine increased. A reduction in the protein intake might result in a disproportionate effect on the IAD of several AAs present in low proportion in the diet but preponderant in the endogenous losses as glycine and serine, as also observed in pigs (Donkoh and Moughan, 1994).

The IAD of CP did not increase with the substitution of lucerne hay with soya-bean concentrate plus a mixture of fibrous ingredients. The lack of effect of source of protein could be partially explained by an increment in the amount of endogenous material as dietary level of inclusion of pulps increased. The endogenous losses represent a high proportion of the total ileal CP flow (García et al., 2004 and 2005). Dietary addition of beet pulp increased intestinal viscosity in rabbits (Volek et al., 2005). It also led to an increase of endogenous secretions and to a reduction in the apparent ileal digestibility of nutrients in broilers (Smits et al., 1997; Langhout, et al., 1999). Other results in pigs (Mosenthin et al., 1994) and rats (Ikegami et al., 1990; Satchithanandam et al., 1990), also indicate that dietary inclusion of viscous substances (apple and citrus pectins, guar gum, or carboxyl methyl cellulose) increased the production of different components of endogenous losses as mucins, intestinal and pancreatic secretions. There are no available data about this subject in rabbits, but the results on apparent ileal AA flow obtained in the present work could confirm this hypothesis. In this way, previous studies (García et al., 2004; Llorente et al., 2006) have shown that endogenous losses in rabbits have a high concentration of aspartic, proline or alanine, whose IAD decreased in our study when dietary pulps concentration increased.

A reduction of dietary CP content from 207 to $179 \mathrm{~g} / \mathrm{kg}$ DM led to a decrease of ileal CP flow by $17 \%$ (from 6.00 (s.e. 0.3 ) to 4.98 (s.e. 0.2 ) g/day) and to a reduction of mortality rate $(P<0.05)$ both during the first 2 weeks after weaning and in the whole fattening period (by 44 
and $46 \%$, respectively). A reduction of fattening mortality rate has been also reported when decreasing the dietary protein to energy ratio (De Blas et al., 1981) or when increasing dietary CP ileal digestibility by including highly digestible vegetable protein sources (Gutiérrez et al., 2003). A high ileal flow of protein has been related to a proliferation of harmful bacteria as Clostridia and Escherichia coli in rabbits (Cortez et al., 1992; Haffar et al., 1988). Data on microbial characterisation of ileal digesta in the present study indicate that the highest correlation observed between the mortality rate in animals not supplemented with antibiotic and the frequency of the compatibility profile of ileal bacteria was for C. perfringens. The presence of this bacterium has been reported in animals affected by ERE, a pathology that affects mainly to young animals aged between 3 and 10 weeks and is responsible for high mortality rates in commercial farms (Pérez de Rozas et al., 2005). This pathology is characterised clinically by the presence of liquid and acid stomachs, which agrees with the lower fundus $\mathrm{pH}$ observed in the present work in animals fed with the diet highest protein content. A positive relationship between level of dietary protein and the intestinal proliferation of $C$. perfringens populations has been also observed in chickens (Drew et al., 2004) and dogs (Zentek et al., 2004).

The supplementation with antibiotics was also effective to reduce the fattening mortality rate, the microbial biodiversity degree (by $67 \%$ ) and the frequency of the compatibility profile of every species studied, including that of C. perfringens. Apramycin sulphate has been previously described in rabbits as an efficacious treatment against the collateral adverse effect of the ERE, reducing the mortality rate from 45 to $10 \%$ when it was added to the drinking water (Badiola et al., 2000). In our study the combined use of this antibiotic with tylosin reduced the mortality rate by $83 \%$. The reduction of dietary protein content additionally contributed to decrease fattening mortality (from 9.6 to $1.9 \%)$. In this case, the reduction of mortality rate can not be explained by a lower presence of $C$. perfringens, which remained low independently of the level of $C P$. Instead, the reduction of the ileal flow of $C P$ was parallel to a decrease of the frequency of the compatibility profile of other potential harmful bacteria, as Helicobacter spp. (from 44.4 to 27.8\%) and Campylobacter spp. (from 38.9 to $31.0 \%$ ). These differences did not reach significant levels, but the average frequency of detection of these bacteria were positively correlated $(r=0.930, P<0.001$ and $r=0.956$, $P<0.001$, respectively) with the average whole fattening mortality of the eight treatments studied.

Our data show that a moderate reduction of dietary CP content did not affect the intestinal morphology in the jejunum, which suggest that the supply of AAs was sufficient to ensure enteric growth. Neither did it impair the growth performance when the total fattening period was regarded, although a higher feed efficiency was observed during the first 2 weeks after weaning in diets with the highest CP content.
The substitution of lucerne hay with soya-bean concentrate plus a mixture of beet and apple pulp, did not affect the ileal flow of CP ( $4.8 \mathrm{~g} / \mathrm{day}$, on average), neither the frequency of the compatibility profile of $C$. perfringens, nor the mortality rate during the first 2 weeks and the whole fattening period. However, the substitution of lucerne hay with dietary pulps and soya-bean concentrate led to changes in the microbial population in the intestinal gut, affecting the frequency of the compatibility profile of several ileal bacteria not correlated with the mortality rate observed in our study, such as Clostridium spp and C. difficile. Variations in microbial population and its fermentation products might also be responsible for the reduction of the caecum $\mathrm{pH}$ observed when dietary pulps were included. These results agree with those obtained by García et al. (1993) and Carabaño et al. (1997) who also observed a reduction on caecal $\mathrm{pH}$ when lucerne hay was substituted with beet pulp.

Our results show that the use of antibiotic is an effective way to reduce the fattening mortality in rabbits by limiting the presence of several harmful bacteria. In addition, decreasing ileal flow of nitrogen compounds obtained by reducing dietary CP level from 209 to $179 \mathrm{~g} / \mathrm{kg}$, affected the composition of the ileal microbiota and especially reducing the frequency of detection of $C$. perfringens. The fattening mortality was also reduced and this might be also contemplated as a helpful strategy for increasing intestinal health and reducing the use of antibiotics. Our results also indicate that the CP requirements to maximise the feed efficiency in the post-weaning period could be higher than those needed to ensure an adequate intestinal health. However, this reduction in feed efficiency obtained during this period was compensated during the whole fattening period.

\section{Acknowledgements}

Financial support was provided by the Spanish Comisión Interministerial de Ciencia y Tecnología (Project AGL 2002-05) and INIA (Project OT00-040-C2-2).

\section{References}

Association of Official Analytical Chemists 2000. Official methods of analysis, 17th edition. Association of Official Analytical Chemists, Arlington, VA.

Badiola JI, Faus C, Pérez de Rozas AM, Gorostiaga 0 and Rosell JM 2000. Mucoid enteropathy: treatment with Apramycin of naturally infected rabbits. World Rabbit Science 8, (suppl. 1B) 195-198.

Blas E and Gidenne T 1998. Digestion of starch and sugars. In The nutrition of the rabbit (ed. JC de Blas and J Wiseman), pp. 17-38, Commonwealth Agricultural Bureau, Wallingford, UK.

Carabaño R, Motta-Ferreira W, De Blas JC and Fraga MJ 1997. Substitution of sugarbeet pulp for lucerne hay in diets for growing rabbits. Animal Feed Science and Technology 65, 249-256.

Cortez S, Brandebruger H, Greuel E and Sundrum A 1992. Investigations of the relationships between feed and health-status on the intestinal flora of rabbits. Tierärztliche Umschau 47, 544-549.

De Blas JC and Mateos GG 1998. Feed formulation. In The nutrition of the rabbit (ed. JC de Blas and J Wiseman), pp. 241-253, Commonwealth Agricultural Bureau, Wallingford, UK. 
De Blas JC, García J and Carabaño R 1999. Role of fibre in rabbit diets. A review. Annales Zootechnie 48, 3-13.

De Blas JC, Pérez E, Fraga MJ, Rodríguez JM and Gálvez JF 1981. Effect of diet on feed intake and growth of rabbits from weaning to slaughter at different ages and weights. Journal of Animal Science 52, 1225-1232.

Donkoh A and Moughan PJ 1994. The effect of dietary crude protein content on apparent and true ileal nitrogen and amino acid digestibilities. British Journal of Nutrition 72, 59-68.

Drew MD, Syed NA, Goldade BG, Laarveld B and Van Kessel AG 2004. Effects of dietary protein source and level on intestinal populations of Clostridium perfringens in broiler chickens. Poultry Science 83, 414-420.

Emaldi O, Crociani F and Matteuzzi D 1979. A note on the total viable counts and selective enumeration of anaerobic bacteria in the caecal content, soft and hard faeces of rabbit. Journal of Applied Bacteriology 46, 169-172.

García Al, De Blas JC and Carabaño R 2004. Effect of type of diet (caseinbased or protein-free) and caecotrophy on ileal endogenous nitrogen and amino acid flow in rabbits. Animal Science 79, 231-240.

García Al, De Blas JC and Carabaño R 2005. Comparison of different methods for nitrogen and amino acid evaluation in rabbit diets. Animal Science 80, 169-178.

García G, Gálvez JF and De Blas JC 1993. Effect of substitution of sugarbeet pulp for barley in diets for finishing rabbits on growth performance and on energy and nitrogen efficiency. Journal of Animal Science 71, 1823-1830.

García J, Carabaño R and De Blas JC 1999. Effect of fiber source on cell wall digestibility and rate of passage in rabbits. Journal of Animal Science 77, 898-905.

Gidenne T 2000. Recent advances in rabbit nutrition: emphasis on fibre requirements. A review. World Rabbit Science 8, 23-32.

Gu X and Li D 2004. Effect of dietary crude protein level on villous morphology, immune status and histochemistry parameters of digestive tract in weaning piglets. Animal Feed Science and Technology 114, 113-126.

Gutiérrez I, García P, Carabaño R and De Blas JC 2000. Effect of supplementation with animal plasma and antibiotics on jejunal morphology of earlyweaned rabbits. World Rabbit Science 8, (suppl. 1C) 263-267.

Gutiérrez I, Espinosa A, García J, Carabaño R and De Blas JC 2002a. Effect of levels of starch, fiber, and lactose on digestion and growth performance of early-weaned rabbits. Journal of Animal Science 80, 1029-1037.

Gutiérrez I, Espinosa A, García J, Carabaño R and De Blas JC 2002b. Effect of starch and protein sources, heat processing, and exogenous enzymes in starter diets for early weaned rabbits. Animal Feed Science and Technology 98, 175-186.

Gutiérrez I, Espinosa A, García J, Carabaño R and De Blas JC 2003. Effect of protein source on digestion and growth performance of early-weaned rabbits. Animal Research 52, 461-471.

Haffar A, Laval A and Guillou JP 1988. Entérotoxémie à Clostridium spiroforme chez des lapins adultes. Le Point Véterinaire 20, 99-102.

Hampson DJ 1986. Alteration in piglet small intestine structure at weaning. Research Veterinary Sciences 40, 32-40.

Ikegami S, Tsuchihashi F, Harada H, Tsuchihashi N, Nishide E and Innami S 1990. Effect of viscous indigestible polysaccharide on pancreatic-biliary secretion and digestive organs in rats. The Journal of Nutrition 120, 353-360.
Lane DJ 1991. 16S/23S rRNA sequencing. In Nucleic acid techniques in bacterial systematics (ed. E Stackebrandt and M Goodfellow), pp. 115-175, John Wiley and Sons, New York, USA.

Langhout DJ, Schutte JB, Van Leeuwen P, Wiebenga J and Tamminga S 1999. Effect of dietary high- and low-methylated citrus pectin on the activity of the ileal microflora and morphology of the small intestinal wall of broiler chicks. British Poultry Science 40, 340-347.

Llorente A, García Al, Nicodemus N, Villamide MJ and Carabaño R 2006. True and apparent amino acids digestibility of sunflower meals, soybean products and peas in rabbits. Proceedings of the XXXI symposium de cunicultura, Lorca, Spain, pp. 117-123.

Maertens $L$ and De Groote $G$ 1988. The effect of dietary protein-energy ratio and lysine content on the breeding results of does. Archiv für Geflügelkunde 52, 89-95.

Maidak BL, Olsen GJ, Larsen N, Overbeek R, McCaughey MJ and Woese CR 1997. The RDP (Ribosomal Database Project). Nucleic Acid Research 25, 109-110.

Merino J and Carabaño R 2003. Efecto de la cecotrofia sobre la composición química de la digesta y sobre la digestibilidad ileal. Información Técnica Económica Agraria 24, 657-659.

Mosenthin R, Sauer W and Ahrens F 1994. Dietary pectin's effect on ileal and fecal amino acid digestibility and exocrine pancreas secretions in growing pigs. The Journal of Nutrition 124, 1222-1229.

Nunez MC, Bueno JD, Ayudarte MV, Almendros A, Rios A, Suarez MD and Gil A 1996. Dietary restriction induces biochemical and morphometric changes in the small intestine of nursing piglets. Journal Nutrition 126, 933-944.

Pérez de Rozas AM, Carabaño R, García J, Rosell J, Díaz JV, Barbé J, Pascual JJ and Badiola I 2005. Etiopatogenia de la enteropatía epizoótica del conejo. Proceedings of the XXXI symposium de cunicultura. Valladolid, Spain, pp. 167-174.

Satchithanandam S, Vargofcak-Apker M, Calvert RJ, Leeds AR and Cassidy MM 1990. Alteration of gastrointestinal mucin by fiber feeding in rats. The Journal of Nutrition 120, 1179-1184.

Smits CH, Veldman A, Verstegen MW and Beynen AC 1997. Dietary carboxymethylcellulose with high instead of low viscosity reduces macronutrient digestion in broiler chickens. The Journal of Nutrition 127, 483-487.

Spanish Royal Decree 1201/2005 2005. Sobre protección de los animales utilizados para experimentación y otros fines científicos. Boletín Oficial del Estado 252, 34367-34391.

Statistical Analysis Systems Institute 1991. User's guide, statistics, version 6.03, edition. SAS institute Inc., Cary, NC.

Van Soest JP, Robertson JB and Lewis BA 1991. Methods for dietary fiber, neutral detergent fiber and nonstarch polysaccharides in relation to animal nutrition. Journal of Dairy Science 74, 3583-3597.

Volek Z, Marounek M and Skrivanova V 2005. Replacing starch by pectin and inulin in diet of early-weaned rabbits: effect on performance, health and nutrient digestibility. Journal of Animal and Feed Sciences 14, 327-337.

Zentek J, Fricke S, Hewincker-trautwein $M$, Ehinger $B$ and Amstberg Gand Baums C 2004. Dietary protein source and manufacturing processes affect macronutrient digestibility, fecal consistency and presence of fecal Clostridium perfringens in adult dogs. The Journal of Nutrition 134, 2158-2161. 